\title{
An integrative literature review of the implementation of micro- credentials in higher education: Implications for practice in Australasia
}

\author{
Ratna Malar Selvaratnam ${ }^{1}$ and Michael David Sankey ${ }^{2}$ \\ Corresponding author: Ratna Selvaratnam (r.selvaratnam@ecu.edu.au ) \\ ${ }^{1}$ Edith Cowan University \\ ${ }^{2}$ Griffith University
}

\begin{abstract}
Micro-credentials research, which includes digital badges, is a relatively new field of study that seeks to inform the implementation, portability and sustainability of the ecology of meaningful delivery. This paper reviews literature relevant to understanding connections between universities' intent to offer micro-credentials and the environment that is needed to do so. From this integrated study, the paper distils a number of core concerns and identifies some gaps in the literature. One of its primary goals is to clear the ground for the construction of a technical model of micro-credentialing implementation that can be used by the various stakeholders involved in the design and evaluation of new micro-awards. A closely related goal is to help those participating in micro-credentialing research to locate and understand each other's contributions, as fragmentation in research related to micro-credentials makes progress in the field slow. Hence, this review draws together research in the field to identify research foci and gaps, and then also capture some work by micro-credentialing researchers that directly attempts to model the main relationships in the field. The paper ends with a summary of implications for practice, especially for the Australasian higher education context.
\end{abstract}

Keywords microcredentials, digital badges, higher education

\section{Introduction}

The Australian higher education sector is on the cusp of recognising what has long been a body of work related to the micro-credentialing space. More broadly, while there is a long history of short courses used for professional development by many professional bodies and more recently the advent of MOOCs, it seems that the sector is still in the seminal stages of agreeing on a common framework for credit, and that there is much to learn about common good practices (Dyjur \& Lindstrom, 2017), thus it is important that this topic be broadly debated and benchmarked. To help further stimulate this process, this paper will set the context of this work with some key constructs present, so far, in the literature.

The field of micro-credentials and how these equate to fuller forms of credentialing is still emerging in the Australian higher education sector (Department of Education and Training, 2018). In the context of this paper, micro-credentials include nano-credentials, digital and open badges. However, to date, general academic literature in this field is limited and even more so in relation to the 
implementation of these credential types, although some lessons can be learned from their antecedents, such as the work being undertaken by Deakin University (Oliver, 2016) and RMIT University (Rossiter \& Tynan, 2019). This paper seeks to provide an analysis of gaps in the current literature globally, through an integrated literature review of micro-credentials. It will then focus on the next steps of implementation in the Australian higher education landscape.

It should be noted that the Australian Federal Government, more recently, announced (June 2020) that they will spend some $\$ 4.3$ million to build and run a one-stop-shop for microcredentials to help students identify educational opportunities (Tehan \& Cash, 2020). Initial indications are that it is intended that an estimated 54 providers will be offering some 344 short online courses on this national platform (Chanthadavong, 2020). At this stage the implications of this are not clear, as the site has not been built yet (at the time of writing), but as a representative form Universities Australia highlights Anything which helps to provide people with qualification and skills for the economic recovery is a good thing (Visontay, 2020).

Several key developments in the field frame the current thinking around micro-credentials in this paper. A recent review of the Australian Qualifications Framework (AQF) was completed in 2019 (Noonan, 2019, also known as the Noonan Review). The findings stress the importance of the AQF being more flexible and responsive to societal needs. In particular, the review highlighted the growing adoption of micro-credentials and how they could allow HEl providers to deliver new programs and courses that may better suit prospective student needs. One recommendation reads:

The AQF Pathways Policy is revised to broaden guidelines for credit recognition across AQF qualifications and to define and provide for recognition of shorter form credentials, including micro-credentials, towards AQF qualifications (p. 9).

This follows the implementation of a similar approach in the New Zealand Qualifications Framework (NZQF) in 2019. Establishing similar (not necessarily the same) guidelines for micro-credentials within the AQF will provide a platform towards assuring a level of quality and commonality that is required for Australian institutions.

Secondly, Emeritus Professor Beverley Oliver from Deakin University, provides a poignant discussion on micro-credentials in the report 'Making Micro-credentials Work for Learners, Employers and Providers' (2019a) which preceded the AQF Review report by 2 months. In it Oliver foreshadowed having the opportunity to have formal qualifications systems which could recognise different forms of credentials. In this report she defines micro-credentials as follows:

... a micro-credential is a certification of assessed learning that is additional, alternate, complementary to or a formal component of a formal qualification (Oliver, 2019b, p. i)

She makes the case for more granular, certified learning which builds trust, adds value and is sustainable through a national credit framework, recognising prior learning for mature learners and implementing lifelong learning accounts through digital systems.

The third document framing the thinking for this paper, that preceded the above, is UNESCO's 2018 report on 'Digital Credentialing: Implications for the Recognition of Learning across Borders'. It proposes a global reference for recognising and negotiating credentials across digital systems. Learning and technology standards are recognised as critical areas to be addressed for credibility in this endeavour. Hence, contemporary national frameworks, such as those proposed in the AQF review, are important quality assurance systems. This of course raises many issues for autonomous national regulatory agencies, but should not be viewed any differently to the way in which other fuller forms of credentials are mediated across borders.

\section{Aims}

Within the context of the AQF Review, the work by Oliver and the UNESCO report, this paper seeks to survey the literature in the field with three key questions. This is done with recognition that the 
field of micro-credentials is relatively new, with an emerging body of literature. Having this in mind, the research questions which this paper seeks to address are:

1. To what extent is there significant literature on micro-credentials generally and on the technical implementation particularly?

2. How can the existing literature on micro-credentials be synthesised to inform the development of a model for the technical ecosystem for the implementation of microcredentials?

3. What are the implications of this model for future practice, particularly in Australasian higher education?

\section{Practical and theoretical rationale for this paper}

A rapidly evolving higher education landscape is an opportunity for Australian universities to reconsider how they offer education (Fawcett, 2018). In a time where knowledge and skills need to be updated constantly, a three- or four-year degree may not suit the currency required in many jobs and other forms of paid and unpaid work. A student's employability and entrepreneurship abilities need to be contemporary and flexible. This point was picked up strongly by the Federal Education Minister, Dan Tehan in a speech at the AFR Higher Education Summit, when he said, institutions are increasingly working with industry to offer micro-credentials and the development of essential capabilities - this needs to continue (Tehan, 2019). He also announced the Commonwealth's support of discounted short courses which could lead up to awards to reskill the population in the COVID-19 pandemic employment fallout (Duffy, 2020). However, recognising them in a way that is translatable across academia and work providers is difficult. Thus, the authors propose that there are two practical rationales for undertaking an integrated study of the implementation of micro-credentials.

In the first instance, while employability is a key measure for Australian university performance, graduates are not finding longer term work matching their awards in a timely or meaningful way as they have in the past (Foundation for Young Australians, 2018). Similarly, though not correlated, short-term graduate employability also dropped slightly in 2019 (GOS National Report, 2019). Coupled with what is termed the Fourth Industrial Revolution, where artificial intelligence is accelerating automation in the future of work, universities need to reconsider their current way of offering awards to meet the much discussed changing nature of employment (World Economic Forum, 2018) and the biggest current challenge of unemployment due to job losses from the COVID19 pandemic (Australian Bureau of Statistics, 2020). The demand for just-in-time and continuous learning is increasing from workers who seek to remain relevant in an ever-changing work environment.

Further, the practical rationale for this paper is to build on the work of Selvaratnam and Sankey (2019). Their findings for the Australasian Council for Open, Distance and eLearning (ACODE) shows the importance of micro-credentialing is growing significantly in Australian higher education institutions. Most institutions already have some form of presence in the space, or are planning to do so. Linking this with the outcomes of the review of the AQF that recommended the recognition of micro-credentials (Campus Morning Mail, 2019) provides an impetus for institutions to consider enabling micro-credentialing frameworks. The low-hanging fruits to establish micro-credentialing in the findings are short courses and postgraduate programs. The recommendations were that higher education institutions should first establish policies to govern this work in their institutions and to establish taxonomies to formalise how micro-credentialing might articulate to their context. The extension of the survey would be an important means to identify gaps detected in the initial findings.

The theoretical rationale for this paper is the dearth of available academic research on microcredentials. Although there is no shortage of opinion pieces published on the internet, many of these lack the required level of academic rigour for an integrative literature review such as this. There is a spread of work on micro-credentials, digital badges, open badges and some mention of 
alternative credentials such as nano-credentials. However, this field is new and maturing with key researchers suggesting areas such as digital badging may be too young for a comprehensive literature review (Gibson et al., 2015). The authors believe that at this point in time, the importance of micro-credentials generally, and in the Australian higher education landscape in particular, is significant enough to now warrant an attempt to pull together key work already done in this field. This will serve to inform future actions for successful implementation and sustainability.

Given the above stated practical and theoretical rationale, the first intention is to investigate the affordances that technology has played in this new and evolving field. To do so both research and industry literature is referred to. The authors argue that 'thought leadership' in the field (Lewin, 2008) is important to include in the discussion. In dynamic time-sensitive fields like educational technology, where a lot of the work on micro-credentialing sits, it is equally important to refer to industry updates as it is to assess the current academic literature in the space. The second intention is to provide a cohesive view on badging including digital and open badging, which is also a new and evolving field. Most micro-credentials rely on a form of recognition which can be shared in marketplaces of learners, employers and education institutions. Usually badges serve this purpose of portable recognition of award.

\section{Key constructs}

This section provides some definitions and discussion points of what is posited here as some key constructs needing to be explored when progressing future micro-credential research. These set the stage for contextualizing the work globally with some emphasis on Australasian higher education. The four areas covered are learning and capability, employability, technology ecosystem, and artefacts and texts.

\section{Learning and capability}

Micro-credentials seek to fill the gap in the current practice of awarding credentials beyond that of degrees. Mostly, adult learning has accelerated the drive for micro-credentials. In a changing workforce seeking to stay relevant in the fourth industrial revolution, continued upskilling and reskilling is pivotal but in chunks of time that are seen to be more manageable.

One of the foundational papers in the field, within the Australian sector, is by Beverley Oliver (2016) laying out the concept, disruption and future of micro-credentials. These are linked to $21^{\text {st }}$ Century skills that, she argues, are necessary for the workforce of the future, especially in Australia. There are some good examples of micro-credentialing already established in Australian higher education, as the following examples illustrate.

In simple terms there are four main models of micro-credentials currently seen within the Australasian sector. These include credentials associated with:

1. Postgraduate short courses and programs based on credentialing demonstrated outcomes, or selling recognition of prior learning (RPL);

2. Postgraduate courses built-up by undertaking a number of shorter courses for academic credit and stacking those credits to attain a recognised award (usually a Graduate Certificate);

3. Undergraduate: where series of short accredited courses may be used to augment a fuller program (typically $x 4=1$ ), that may replace one or two courses (units) in a 24 course (unit) program. These are typically skill based;

4. Undergraduate: non-accredited, or co-curricular courses to demonstrate experience and enhance a student's portfolio with the view to enhancing employability prospects. (Sankey, 2019)

This leads to the current trend in the sector that is seeking to try and chorale this at a national policy level, one that would formally recognise micro-credentials. Countries such as New Zealand already 
recognise micro-credentials (Education New Zealand, 2018). The New Zealand Qualifications Authority (NZQA) will quality assure the learning included in each micro-credential, having incorporated micro-credentials into the overall quality assurance framework. However, in the case of Australia this will need to be aligned in some way with the AQF (Australian Qualifications Framework), which is structured differently to the New Zealand model. This was flagged by TEQSA in their 'Guidance Note: Technology-Enhanced Learning, Version 1.2', released on 11 April 2019, where they specifically called out the granting of credit for new forms of prior learning in the TEL (Technology Enhanced Learning) environment, such as completion of a MOOC or micro-credential (TEQSA, 2019).

Figure 1 shows Gallagher's (2016) depiction of the emerging markets that though currently distinct, are converging especially around the micro-credentials space and the current short offerings which are not credentialed. Research has shown that this convergence is easier accomplished by universities than trying to unbundle traditional awards (Selvaratnam \& Sankey, 2019). It also crucially affords university partnerships especially those that leverage on employment opportunities for graduates.

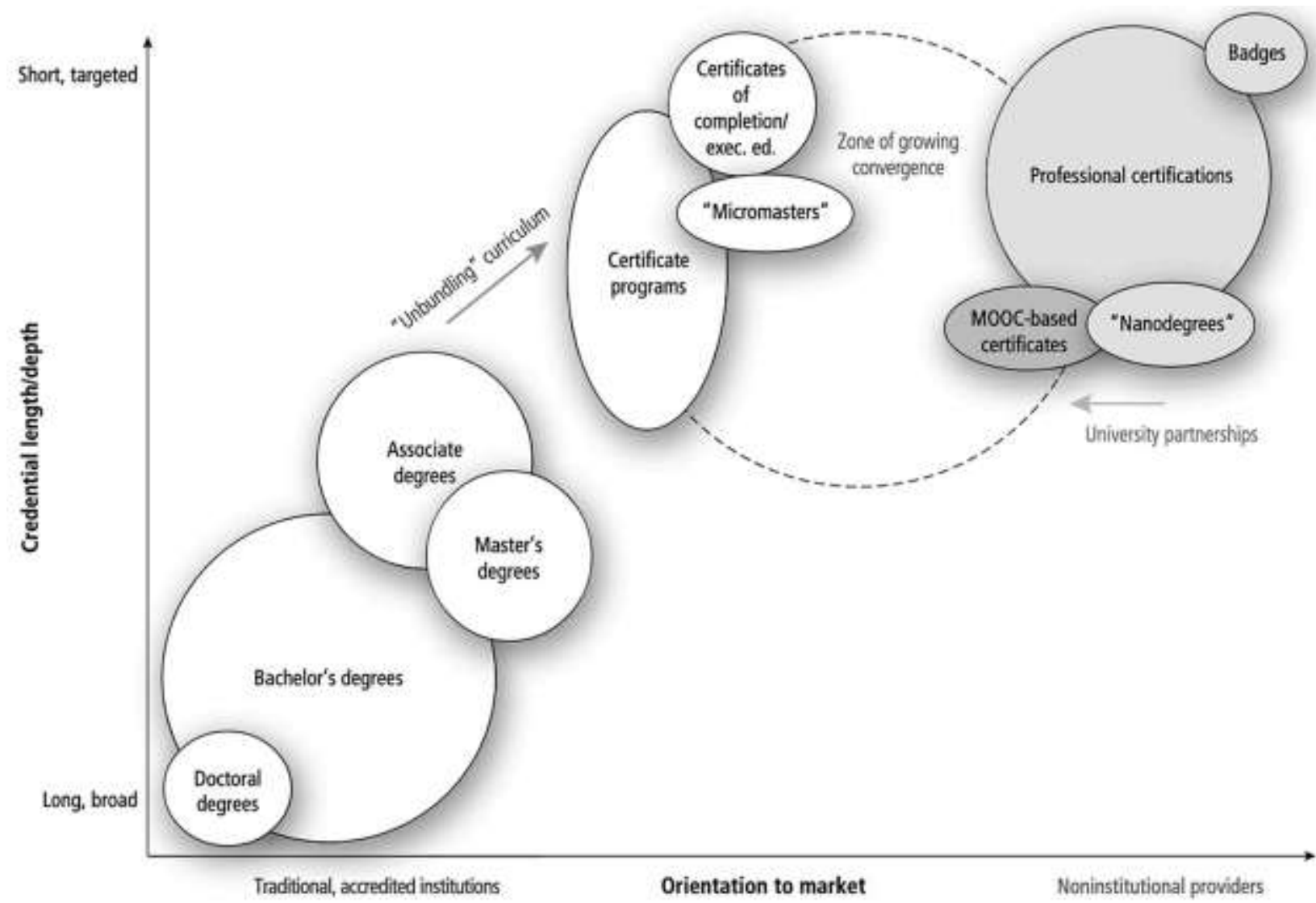

Figure 1: The Credential Landscape: Market Size and Orientation and Credential Duration (Gallagher, 2016)

\section{Employability}

The second construct is employability. Australia has a strong emphasis on the employability of university graduates with government funding now formally tied to this measurement. The metric is clear in terms of when a graduate is expected to be actively employed and the type of employment contract (Department of Education, Skill and Employment, 2019). Governments have recognized the need for adult learners to stay relevant through upskilling and reskilling for the workforce and have taken steps to regulate and provide opportunities for adult learners to meet this need. More 
specifically, the Education Minister Dan Tehan specifically called this out, in reference to the recent AQF review, when he said:

The Review has been looking at recognition of micro-credentials and better alignment of higher education and vocational training skills, changes to volume of learning, possible credit point systems, and clearer alignment between learning and occupational outcomes. (Tehan, 2019)

An example, or hint as to how some State based tertiary admissions centres are handling this can be seen with the work of QTAC (Queensland Tertiary Admissions Centre), in their submission to the AQF review. In their submission they write:

At QTAC we engage daily with prospective students who are anxious about the future and their ability to compete in a changing workforce. Over the last two decades QTAC has seen a profound shift: where there was confidence about the power of tertiary education to ensure gainful employment and swift advancement, there is now uncertainty about whether it offers a return on investment for the learner. Those of us within the sector understand the many practical and personal benefits of higher education, but we are sympathetic to those who struggle to determine the value when media points to the underemployment of graduates from all disciplines... The change is most evident in the rise of non-formal and informal corporate training, particularly 'micro' credentials. Much of the training that is undertaken by working Australians today is not recognised within the AQF, a distinct shift from the time when Corporate Australia would sponsor its future leaders through formal qualifications. The rise of microcredentials reflects the corporate need for targeted, short and inexpensive skill and knowledge development, as well as the motivation of individuals to future-proof themselves against change. (Griffiths University, 2019)

The perspective presented in this work is not insignificant and is leading to a number of practical outcomes in universities within Queensland, not the least of which was the development of a taxonomy of credential types and definitions at Griffith University (Griffith University, 2018).

Many governments in OECD countries have also initiated improvements to the governance of adult learning systems (OECD, 2019). In addition to manageable learning chunks with reference to time, the skills on offer are also important for learners. Relevance to industry is also highlighted as an important factor to ensure the success of shorter form credentials (Saray \& Ponte, 2019), as learners are likely to take up what they perceive as important to their work roles. The agreed premise is that badges, which are one of the artefacts signifying the completion of a micro-credential, are only valuable to employers as the skills they evidence through mastery rather than participation (Carey \& Stefaniak, 2018). This is a separate discussion to what a learner may take for leisure, where evidencing their learning may not be a priority.

Other countries have set up national systems for continued learning and capture of the evidence of an individual's accomplishments that can be shared, especially with future and current employers. Examples of countries with portable lifelong learning credit banks include Singapore (SkillsFuture, 2019) and the current work in Sweden on a national strategy for validation (Valideringsdelegationen, 2019). There are several regional qualifications frameworks encouraging portability and recognitions between member countries including The Association of Southeast Asian Nations Qualifications Reference Framework, The Caribbean Community Qualifications Framework, The Economic Community of West African States Qualifications Systems, The European Qualifications Framework, The Pacific Qualifications Framework, The Southern African Development Community Qualifications Framework: Building Trust For Better Mobility, and The Transnational Qualifications Framework for the Virtual University For The Small States Of The Commonwealth (CEDEFOP, 2019). These regional frameworks are significant as they cross borders and carefully consider employability and meaningful contribution to the collective economic health of the region. 


\section{Technology ecosystem}

The third key construct of this paper is the technology ecosystem that enables the learning and delivery of micro-credentials. There are a variety of methods to offer micro-credentialing. Universities can adopt unbundled learning pathways to maximise opportunities in the sector. Unbundling is the process of disaggregating educational provision into its granular component parts. With suitable and flexible modes of credentialing, this provides ease of movement, portability, and mobility (Czerniewicz, 2019). However, there needs to be a meaningful way to understand what these varieties of credentials mean for stakeholders such as employers. One way to do that as suggested in EDUCAUSE (2018) is using the Credential Transparency Description Language (CTDL) where common terms are used that are recognised by search engines and credential publishers.

While there are several means to offer micro-credentials, there continues to be the debate on how best to verify these credentials, especially if they are to be portable between institutions and sectors. McArthur (2018) suggests blockchain technology, which is generally defined as 'distributed digital ledgers', to be one solution to this. Blockchain technology is regarded as a disruption to the way education is now offered (Jirgensons \& Kapenieks, 2018), primarily certified by the institution which offers the award. For example, in Australia and New Zealand, certified digital documents are already offered by all universities in a central repository called eQuals (2019), however this does not include micro-credentials as yet.

The other discussion worth noting is within digital credentialing. In the 'Next American Economy's Learning Series', the Roosevelt Institute (2016) offers guiding principles to navigate this increasingly digital space affording credentialing. Ifenthaler, Bellin-Mularski, and Mah (2016) explore digital badging specifically focusing on its technical elements in all levels of learning. Open badges are also a form of digital badging awarded at completion of learning. This is another discussion on badging, usually linked to learning management systems (Liyanagunawardena, Scalzavara, \& Williams, 2017). Open badges are open source products which can be accessed by a wide range of institutions. EdSurge (2018) which curates digital badge offerings, mainly on North America, includes the work $\mathrm{EdX}$ is doing on their 'MicroBachelors' program. EdX is a key Massive Open Online Course (MOOC) provider.

Other platforms to consider in the micro-credential technology ecosystem include The IMS Global Consortium (2019) which offers Open Badges (BBv2). These are verifiable micro-credentials that fill the gap in traditional transcripts and resumes. Also, the Lumina Foundation's Credential Engine (2019) is a not for profit enterprise trying to fill the gap for a common descriptive language for credentialing that is searchable in a common marketplace.

West and Lockley (2016) emphasise the investment in key infrastructure in technology, in addition to curriculum, policy, processes and training. The technology ecosystem needs to be robust enough to reduce manual work for both issuers and learners, ensure quality and authenticity, and facilitate visibility and compatibility of need for employers (Markowitz, 2018). In the short courses market the buyer would be employers (Callaghan, 2019), and these are generally the easiest to convert to micro-credentials (Selvaratnam \& Sankey, 2019). However, employers need to be assured of quality and this remains a challenge (Krupnick, 2019, Jagger, 2019). Some successful badges are co-created between the potential employer and the university (Leaser \& Gallagher, 2017), thus ensuring the quality for the possible future employer from the beginning.

\section{Artefacts and texts}

The fourth construct is of the available artefacts and texts on micro-credentials. This is best evidenced by the current work in sample universities. There are three examples in Australia which are relevant. The RMIT University approaches micro-credentialing as a means of certifying smaller attainments of learning than that of a full degree. This insight includes stackable credit, general recognition of prior learning, evidence of graduate attributes and standards-based competencies 
associated with professional practice. RMIT Creds (2019) is available to all enrolled students. They are generally online and self-paced. Students are awarded a digital badge upon completion.

Another example is DeakinCo (2019), a fully owned private subsidiary of Deakin University that works in the recognition of prior learning space which translates into, what they term, Professional Practice credentials and awards. These are higher education pathways to Deakin University but also providing vocational education and training. They brand themselves as 'workplace learning and recognition specialists'. Other institutions, such as Griffith University (2019) already have a microcredentialing policy and a taxonomy of practice that aligns levels of activity with a multilayered schema of credentials, ranging from, 'for academic credit' to 'recognition of attainment'.

In Europe, the research by MicroHE (2019) is a significant piece of work currently in development. It aims to provide the most comprehensive analysis yet conducted of the impact of modularization, unbundling and micro-credentialing in European Higher Education. As another example, EDUCAUSE (2019) provides a space for higher education practitioners to organically collaborate and interact on the work on micro-credentials and digital badges, including research, design and implementation. This is for global participants but tends to have more North American participation. In the U.S., the State University of New York (SUNY) (2019) have outlined the implementation of micro-credentials into four groups leading the work around transferability and portability, data reporting, policy/financial aid, and readiness, training and assessment. This work is both strategic and operational in approach and may be a good example for universities starting on the microcredentialing journey.

\section{Micro-credentialing research in higher education: Focal areas}

\section{Approach taken}

The aim of the paper is to provide a snapshot of the practice of micro-credentialing as discussed in the sections preceding, categorising the research work done to date in the field, then synthesise this work into a conceptual model designed to provide next steps for the conversation in implementing and sustaining the work. The method used is an integrative literature review (Russell, 2005), which is a form of research that reviews, critiques, and synthesises representative literature on a topic in an integrated way such that new frameworks and perspectives on the topic are generated (Torraco, 2005 , p. 356). It is a distinct form of research without much guidance in the field and is useful for both mature and new fields of study, this paper being the latter.

The approach taken to achieve this is outlined in the following steps. Firstly, all academic literature reviewed in this paper is from 2016 onwards. While industry work is referred to in this paper for context, the scope of the integrative literature review is to identify academic papers in the main and key reports where relevant. Ifenthaler et al. (2016) completed a comprehensive reference to the work on digital badging in 2016. Mah's (2016) systematic review of the literature focused on the nexus between learning analytics, digital badging and student retention, while Liyanagunawardena et al. (2017) undertook a systematic review of the literature on open badges in 2017. All three provide key foundations for the discussion on micro-credentialing through the study of digital badging, but do not address micro-credentials as a focus. A lot of what is covered in this current review of literature seeks to build on the work done since these three studies, due to evolution and acceleration of policy, demand and technology.

Second, a search through library databases was run on 'digital badges' and 'micro-credentials' including the term 'technical implementation of micro-credentials'. A search of 'micro-credentials' which is a fairly new term used by Oliver (2019a) did not return meaningful results. Results linked to university libraries' use of micro-credentialing was left out of the paper as it is usually very specific to library skills and not related to academic awards. While significant, the authors wanted to focus on universities' central efforts in providing micro-credentials. 
Thirdly, an internet search was run on 'micro-credentialing' to look at industry takes on the subject. As the focus of this paper is on a new and emerging field that can fall under the educational technology umbrella, it was important to also keep abreast of the currency of innovation and implementation in the field. Finally, the authors also used some citation chaining to ensure there was no relevant research missed.

\section{Table 1: Recent Key Research in the Field of Micro- credentials}

Key literature in micro-credentials

\begin{tabular}{l|l|l}
\hline \multicolumn{1}{c|}{ Literature type } & \multicolumn{1}{c}{ Micro-credential } & \multicolumn{1}{c}{ Badging (Digital \& Open) } \\
\hline Systematic review & Calonge et al (2019) & $\begin{array}{l}\text { Liyanagunawardena et al (2017) } \\
\text { Mah (2016) }\end{array}$ \\
\hline $\begin{array}{l}\text { Empirical research and } \\
\text { conceptual papers }\end{array}$ & $\begin{array}{l}\text { Gallagher (2016) } \\
\text { Ghasia et al (2019) } \\
\text { Jirgensons, M. and Kapenieks, J. } \\
\text { (2018) }\end{array}$ & $\begin{array}{l}\text { Coleman (2018) } \\
\text { Newby and Cheng (2019) } \\
\text { Hickey and Grant (2019) } \\
\text { Abramovich (2016) } \\
\text { Morris et al (2019) } \\
\text { Tierney et al (2019) } \\
\text { Roy and Clark (2019) } \\
\text { DiSalvio (2016) } \\
\text { Farmer and West (2016) } \\
\text { Ifenthaler et al (2016) }\end{array}$ \\
& & \multicolumn{2}{|c|}{$\begin{array}{l}\text { Spaulding and Johnson (2016) } \\
\text { Reports and whitepapers }\end{array}$} & $\begin{array}{l}\text { Oliver (2016) (2019a) } \\
\text { Selvaratnam \& Sankey (2019) }\end{array}$ \\
UNESCO (2018) & \\
\hline
\end{tabular}

Table 1 shows key literature in micro-credentials. A lot of the work would be media or industry articles, mostly in education technology thought leadership pieces, rather than academic research. The former is not represented in the table but some are discussed elsewhere in this paper. Three reports and whitepapers are included. The table highlights work in the micro-credentialing space and also badging which has a little work published academically. However, it is still maturing.

There is currently limited literature on implementing micro-credentials. Some of the key work in the area is discussed here. The seminal work in this is that of Beverley Oliver (2016) where she lays out the foundation of micro-credentialing in a widely quoted whitepaper. Selvaratnam and Sankey (2019) conducted a survey of Australian universities to assess the perception of micro-credentialing. Their findings detailed there was high awareness and intent or planning for micro-credentials, but low implementation at this point in time. While this review refers to MOOCs, Calonge, Shah, Riggs, and Connor, (2019) also refer to credentialing them to help address skills shortages and upskill employees in an Australian context. Ghasia, Machumu, and de Smet's (2019) findings suggest the university community finds micro-credentialing a positive step forward, but needs a robust ecosystem of policy, infrastructure and skill base to ensure success. Gallagher (2016) posits that while it is accepted that credentialing is central to higher education perhaps it is the credentialing mechanism that is in need of innovation and key to understanding and generating new models and greater value (p. 19). Jirgensons and Kapenieks's (2018) work focuses more on the technology that ensures credentialing quality especially in assessment, suggesting blockchains would be a solution. UNESCO's 2018 report proposes a global reference for recognising and negotiating credentials across digital systems.

Digital badging, while still a new field, has prompted more literature and studies. There has been work done to evaluate badging platforms (Hamson-Utley \& Heyman, 2016. Dimitrijevic, Devedzic, Jovanovic, \& Milikic, 2016), though new platforms are constantly entering the market. Mah (2016) 
adds to the conversation by proposing a model that synthesizes learning analytics, generic skills and digital badges to promote student retention. Ifenthaler et al. (2016) explore digital badging specifically focusing on its technical elements in all levels or learning, with many authors from around the world contributing. Liyanagunawardena et al., (2017) conducted a systematic review of open badges while acknowledging it was still in its infancy. Spaulding and Johnson (2016) directly link employment goals to badging for youth.

Hickey and Chartrand (2019) posit that their study of 30 funded efforts to develop badges found participation badges for engaged social learning created better thriving ecosystems compared to competency badges. In addition to badging for main awards, a complementary area for badging in universities is in co-curricular activities. Evidence shows that while it connects learners to their curricular journey meaningfully, the platform would ideally afford natural stimulation of intrinsic and extrinsic motivation for students to engage (Coleman, 2018). Newby and Cheng (2019) reported in their study digital badges both afforded higher levels of perceived confidence in learners and higher performance in outcomes. Further, Abramovich (2016) argues some learners can benefit by badges that are also designed to be assessments.

On the other side of the debate, however, Morris et al. (2019) surprisingly, found no significant improvement in learning when they conducted an experiment on students to determine if badges support self-regulated learning. One way to mitigate the lack of perceived value in digital badges is for there to be a co-design process with learners on responsive badge systems (Tierney, Horstman, \& Tzou, 2019). Despite the challenges, the debate continues and clearly more research is needed particularly in diverse contexts (Roy \& Clark, 2019), digital badges remain significant (DiSalvio, 2016; Farmer \& West, 2016). The debate around digital and open badges demonstrates its importance, gaps remain in the literature.

\section{Representations of micro-credentials implementation}

While the academic literature in the field of micro-credentials is limited, there have been several attempts to effectively model the relationship of various stakeholders together with the process and technical infrastructure necessary.

Oliver's (2019a) model in Figure 2 charts a distinct role for employers in the ecosystem. As discussed earlier, credentials are usually successful if they are relevant for current and future employers. Importantly, she suggests third party providers partner with industry to offer credentials. Employers themselves can offer credentials in-house or in partnership with other organisations. This is where Oliver seems to suggest that universities or higher education providers can become the partner of choice with employers and other credentialing providers, be they public or private. This would require universities to rethink how they do business going forward as they are not the sole credentials provider but potentially have a wider reach through partnerships to offer access to learners who want qualifications beyond traditional awards or degrees. The design of the credential also becomes more relevant as it would be a backward design models from what is needed in the world of work to the type of digital credentials that are suitable which in turn informs module design (Rossiter \& Tynan, 2019). 


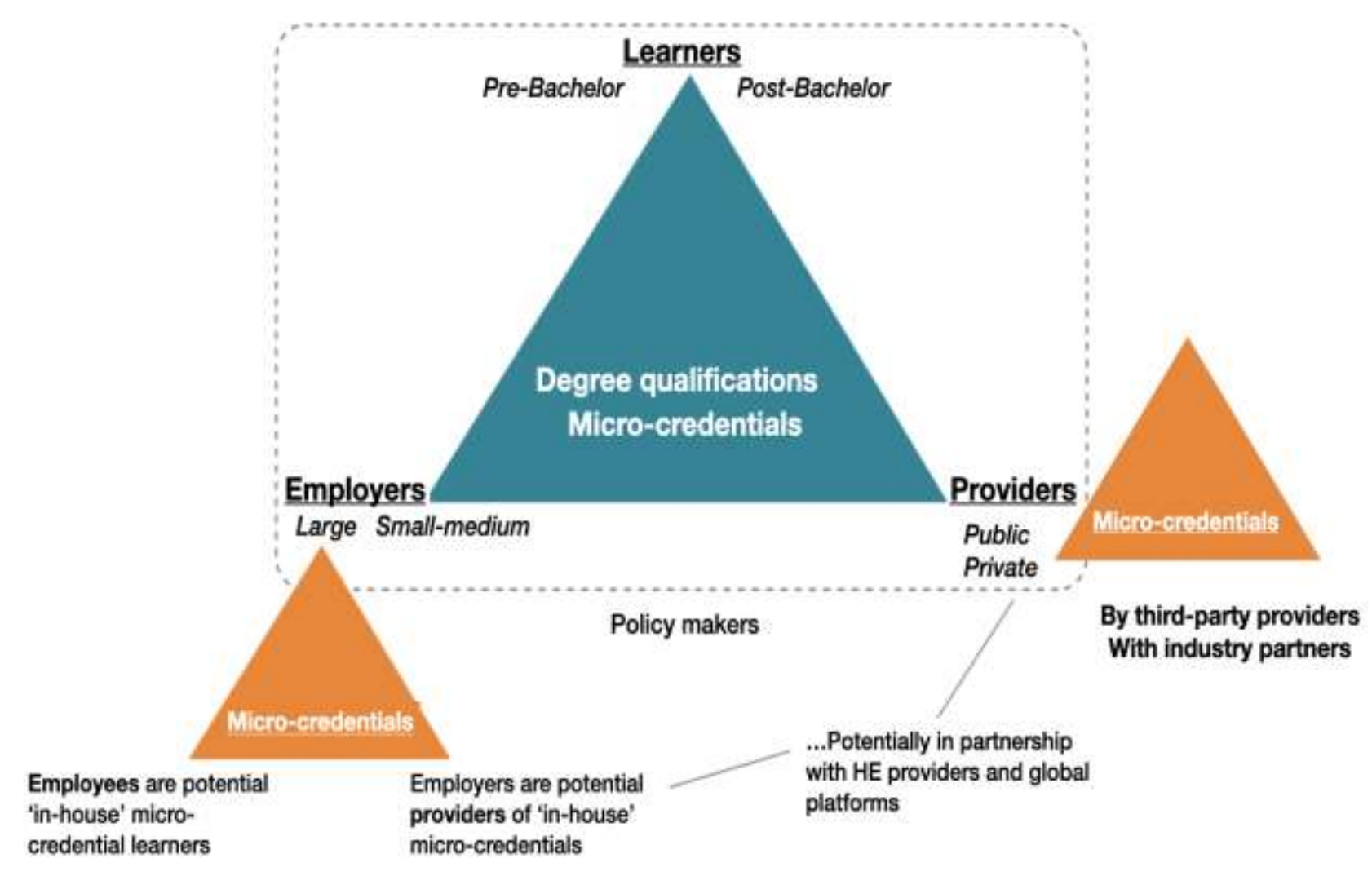

Figure 2: Today's Evolving Micro-credential Ecosystem with Major Employers and More Private Providers Offering Micro-credentials (Oliver, 2019b)

While Oliver's (2019a) model depicts the delivery of micro-credentials, Rossiter and Tynan (2019) suggest what the learner's journey would look like in Figure 3.

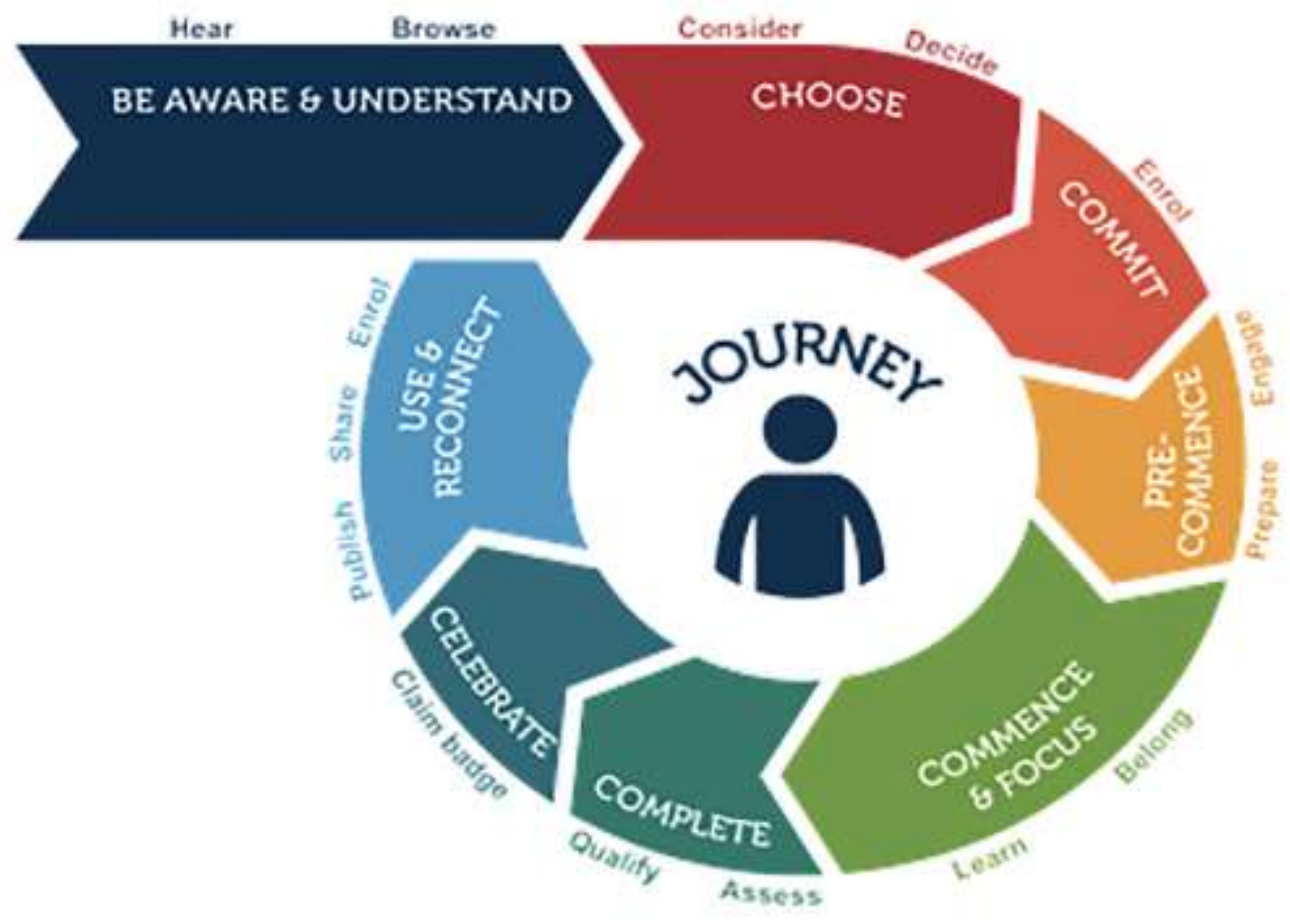

Figure 3: The Learner-and-Earner Micro-credential Journey (Rossiter \&Tynan, 2019)

Selvaratnam, R.M., \& Sankey, M.D. (2020). An integrative literature review of the implementation of micro-credentials in higher education: Implications for practice in Australasia. Journal of Teaching and Learning for Gradate Employability, 12(1), p. 1-17 
The learner is now also an earner, stacking learning credentials as they go along their lifelong learning journey. Agency is very much with the learner as they are first made aware and understand the credential on offer, then choose from the options at hand, likely from their own research. They then commit to the learning experience through the stages of prepare and commence, then qualify upon completing an authentic assessment. They then claim the badge or credential and then, most importantly, share their credential usually by publishing it in a marketplace like LinkedIn or a public portfolio where it will be highly visible.

A model was also developed by UNESCO (2018) in analysing what works and what does not in a high-level digital ecosystem for credentialing. Building on Oliver's model of delivery and consumption, and Rossiter and Tynan's model of the learner as agent, the architectures provided begin to map out the digital dependencies of a digital ecosystem at a macro level. Five architectures are identified; central repository, exchange network, hub-and-spoke, badge framework, and public blockchain. Each architecture is analysed against the four areas of scope and functionality; mobility; security, trust, privacy; and participation detailing the benefits and challenges of each.

While the models discussed are significant, what does this mean for a university's technical ecosystem for micro-credentials? In Figure 4 (below) the authors suggest a simple model linking the key stakeholders and their relationship in the technology continuum distilled from the preceding discussions. The journey begins with the learner who seeks to earn the credential i.e. learner-asearner. The learner would typically interact with learning technologies which would enable discovery of content, platform or direction for collaboration and access to authentic assessment; in other words, a virtual learning environment (VLE), which includes an LMS and associated systems such as ePortfolio, lecture capture, peer learning tools, etc. This would be earned from offerings from a higher education provider who manages the administrative technologies that enable the earning of the credential. These would include student management systems (SMS), including enterprise communication systems and quality assurance processes. These credentials then would be made visible for employers to access in a single subscribed or multiple marketplace common to all three stakeholders, managed by third party providers; credentialing management systems (CMS) that generally include virtual backpacks to hold the digital credentials or badges earned. An example of a single marketplace would be the use of My eQuals in Australia. Multiple marketplaces would be the addition of public marketplace technologies such as Linkedln.

The outer ring is the employer, who is able to make hiring decisions based on the qualifications made visible in the marketplace; professional representation systems (PRS). It is important to note that for a successful model for micro-credentials, all four stakeholders will already be in conversation from the beginning, hence the represented relationship. For example, the microcredential would already have been tested in the marketplace and possibly co-created with the employer to ensure relevancy. This model provides a simple technology map that can be adapted to multiple higher education scenarios based on the type of offering and access to relevant technologies.

Importantly, when designing for micro-credentials, institutions need to be aware of the multiple systems and how these systems need to interact with each other. For example, when choosing a credentialing engine it is important that this particular tool will faithfully represent the badge, or credential, in the systems that will be seen by potential employers, which is not always the case. This disjoint was personally experienced by one of the authors when the badges issued by the institutions credentialing engine where not viewable in the institutional ePortfolio system. 


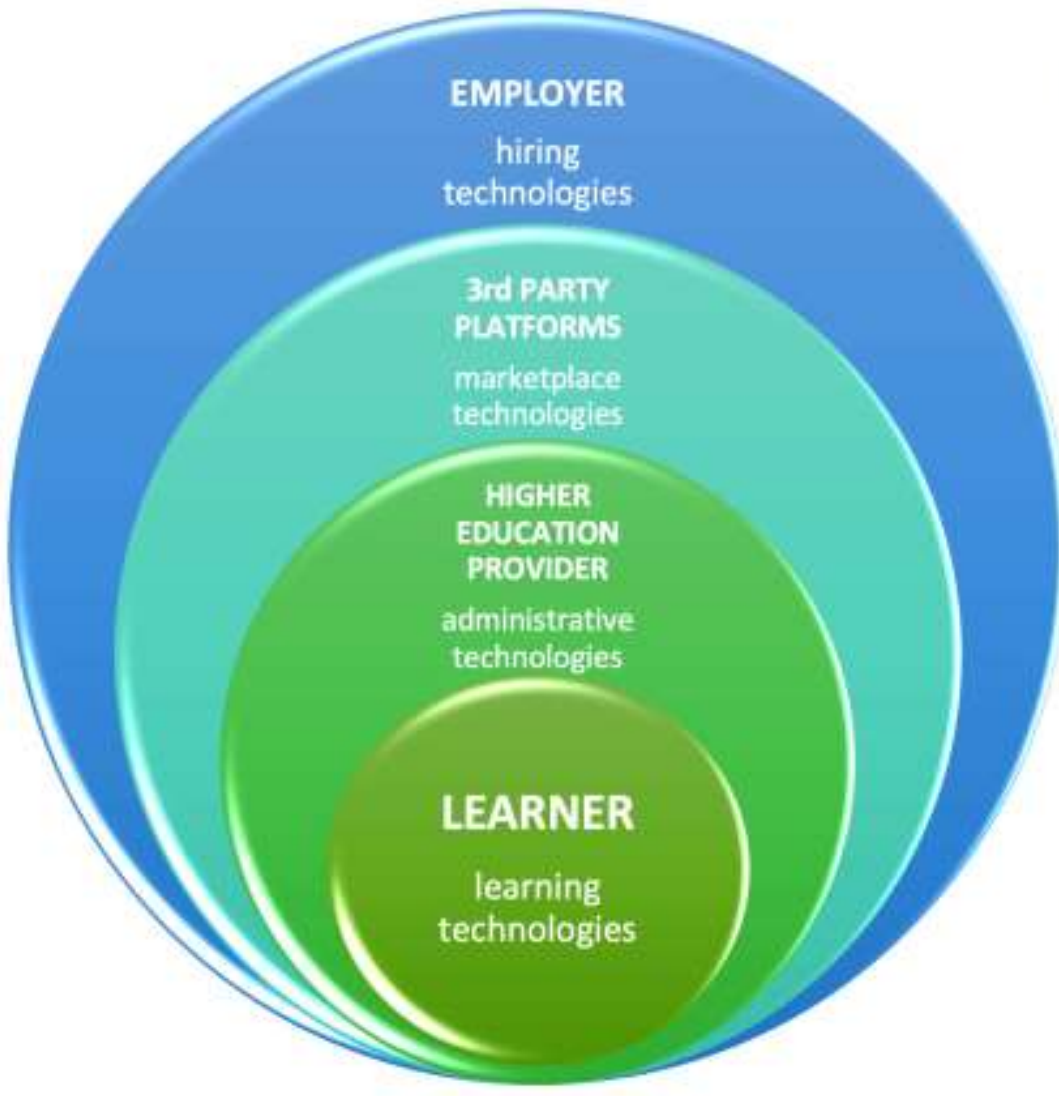

- Systems that allow for the
representation of select
credentials for
professional consumption
CMS
- Systems where public
facing credentials are
stored, shared \& validated
by a accredited bodies
SMS
-Institutional systems
where student's identity is
assured and where
qualifications are
mediated
VLE
- Systems where learning
occurs and where
assessment is validated

\section{Figure 4: Micro-credentials and Stakeholder Engagement with Relevant Technologies}

\section{Implications for future research and practice}

There is a significant gap in academic research in the field of implementing and sustaining microcredentials in higher education. Much of the work is done in industry thought leadership and design and also in media articles. There is some work published recently on digital badging, but less in micro-credentialing, and even these tend to be whitepapers and reports. Additionally, the success of micro-credentials relies on the acceptance and need of future employers who may want to access this evidence. Hence, the field of micro-credentials can benefit from wider empirical research especially integrating with employability. There also needs to be deeper research on the technical implications of successful micro-credentials rollout so that the processes that the authors suggest in Figure 4 are clearly transacted. This is precisely where an agreed national framework for the recognition of micro-credential would play such an important role. Not only would it help institutions fall within agreed parameters, but it would provide tertiary admission agencies clear guidance as to what is acceptable for university entrance. Such a framework would also provide future researchers a base-level from which to expand their understanding as one of the limitations of this study, has been the challenge of making sense of a range of different central processes found in higher educational institutions. Also while some works in co-curricular micro-awards are mentioned, this has not been explored in-depth.

\section{Conclusion}

This paper has looked at the overall implications for theory and practice of micro-credentialing implementation while emphasizing the Australasian landscape. It is noted that an understanding of micro-credentialing is growing significantly in Australasian higher education institutions and many 
institutions already have presence in the space, or are planning to do so very soon (Selvaratnam \& Sankey, 2019).

At a very practical level, the recent review of the Australian Qualifications Framework recommends the recognition of micro-credentials and presumably it is only a matter of time before the government moves to implement this recommendation. This provides the additional impetus for institutions to consider micro-credentialing. As has been suggested, the low-hanging fruits would be short courses and postgraduate programs that could be the first offerings in a university to be micro-credentialed. An area for higher education institutions to work on would be to have policies and associated taxonomies to govern this work in their institutions and to formalise the place for micro-credentialing in their offerings.

Given the above were also the findings from Selvaratnam and Sankey (2019)'s research, there is a need to extend the research formally to inform institutions on meeting the recommendations in the AQF review around micro-credentialing and the global trends in this space. This survey was undertaken by representatives for member institutions within the ACODE network, however, there is a small number of institutions (four) in Australasia that are not a part of this Council. Furthermore, there is a small number of ACODE member institutions that did not completed this survey. It would also be good to extend this survey to these institutions and to gain more qualitative data to provide a deeper level of understanding as to the directions these institutions are anticipating this will play out for them. This will provide an even more robust picture of the current state of microcredentialing in the Australasian sector. The implications for practice will be providing institutions with a broader understanding of the learning experience across the sector in relation to the practice of implementing micro-credentialing.

\section{References}

Abramovich, S. (2016). Understanding digital badges in higher education through assessment. On the Horizon, 24 (1), 126-131.

ACODE (2019) Australasian Council on Open, Distance and eLearning website. Retrieved from: https://www.acode.edu.au

Australian Bureau of Statistics. (2020). Labour Force, Australia. May 2020. 24 June. Retrieved from: https://www.abs.gov.au/ausstats/abs@.nsf/mf/6202.0

Barabas, C., \& Schmidt, J. P. (2016). Transforming chaos into clarity: The promises and challenges of digital credentialing. USA: Roosevelt Institute. Retrieved from: http://rooseveltinstitute.org/promises-andchallenges-digital-credentialing

Callaghan, R. (2019). Surge in university micro-credentials. The Australian Financial Review. Melbourne. 23 May.

Calonge, D., Shah, M., Riggs, K., \& Connor, M. (2019). MOOCs and upskilling in Australia: A qualitative literature study. Cogent Education. 6(1). Retrieved from: https://www.tandfonline.com/doi/full/10.1080/2331186X.2019.1687392

Campus Morning Mail. (2019). Micro-credentials: They will be a happening thing. 12 December. Retrieved from: https://campusmorningmail.com.au/news/micro-credentials-they-will-be-a-happening-thing/

Carey, K., \& Stefaniak, J. (2018). An exploration of the utility of digital badging in higher education settings. Education Technology Research Development. 66(1), 1211-1229. Available at: https://doi.org/10.1007/s11423-018-9602-1

CEDEFOP. (2019). Global inventory of regional and national qualifications frameworks 2019: Volume 2: National and regional cases. Retrieved from: https://www.cedefop.europa.eu/en/publications-andresources/publications/2225

Chanthadavong, A. (2020). Australian government to build AU\$4.3 million online microcredentials marketplace. ZDNet. 22 June. Retrieved from: https://www.zdnet.com/article/australian-government-tobuild-au4-3-million-online-microcredentials-marketplace/

Coleman, J. (2018). Engaging undergraduate students in a co-curricular digital badging platform. Education and Information Technologies. Springer. 23(1), 211-224. DOI 10.1007/s10639-017-9595-0

Czerniewicz, L. (2019). Unbundling and rebundling higher education in an age of inequality. EDUCAUSE. Retrieved from: https://er.educause.edu/articles/2018/10/unbundling-and-rebundling-higher-educationin-an-age-of-inequality 
Credential Engine (2019). Making all credentials transparent and revealing the marketplace of credentials. Retrieved from: https://credentialengine.org/

DeakinCo. (2019). Retrieved from: https://www.deakinco.com/

Department of Education, Skills and Employment (2018). Incorporating shorter form credentials into the AQF. Retrieved from: https://docs.education.gov.au/documents/incorporating-shorter-form-credentials-aqf

Department of Education, Skills and Employment. (2019). Performance-based funding for the Commonwealth Grant Scheme. Retrieved from: https://www.education.gov.au/performance-based-fundingcommonwealth-grant-scheme-0

Dimitrijevic, S., Devedzic, V., Jovanovic, J. \& Milikic, N. (2016) Badging platforms: A scenario-based comparison of features and uses. In D. Ifenthaler, N. Bellin-Mularski \& D-K. Mah, (Eds.), Foundation of Digital Badges and Micro-Credentials: Demonstrating and recognizing knowledge and competencies (pp. 141-161). Switzerland: Springer. Available at: https://www.springer.com/gp/book/9783319154244

DiSalvio, P. (2016). New pathways to credentialing: The digital badge. New England Board of Higher Education. Available at: https://nebhe.org/journal/new-pathways-to-credentialing-the-digital-badge/

Duffy, C. (2020). The Government wants you to switch from Netflix to an online short course during coronavirus isolation. ABC News, 14 April. Retrieved from:

https://www.abc.net.au/news/2020-04-14/online-courses-to-keep-you-busy-during-coronavirusisolation $/ 12144718$

Dyjur, P., \& Lindstrom, G. (2017). Perceptions and uses of digital badges for professional learning development in higher education. TechTrends. 61, 386-392. DOI 10.1007/s11528-017-0168-2

Education New Zealand (2018). NZQA approves micro-credentials. Education News, 1 August. Retrieved from: https://enz.govt.nz/news-and-research/ed-news/nzqa-approves-micro-credentials/

EdSurge Guide. (2018). A Lifetime of Back to School: Micro-credentials in Higher Education. Retrieved from: https://www.edsurge.com/research/guides/a-lifetime-of-back-to-school-microcredentials-in-highereducation

EDUCAUSE. (2018) The Credential Transparency Description Language. Retrieved from: https://library.educause.edu/ /media/files/library/2018/12/eli7163.pdf

EDUCAUSE. (2019). Micro-credentials and badges community group. Retrieved from: https://www.educause.edu/community/microcredentials-and-badges-community-group

Farmer, T., \& West, R. E. (2016). Opportunities and challenges with digital open badges. Educational Technology, 56(5), 45-48. Retrieved from: http://www.academia.edu/29863552/Opportunities_and_Challenges_with_Digital_Open_Badges

Fawcett, K. (2018). Lifelong learning and reskilling: The promise of micro credentials. The Foundation for Young Australians, Newsletter. 21 September. Retrieved from: https://www.fya.org.au/2018/09/21/lifelonglearning-and-reskilling-the-promise-of-microcredentials/

Foundation for Young Australians. (2018). The new work reality. Retrieved from: https://www.fya.org.au/wpcontent/uploads/2018/06/FYA TheNewWorkReality sml.pdf

Gallagher, S. R. (2016). The future of university credentials: New developments at the intersection of higher education and hiring. Cambridge, MA: Harvard Education Press.

Ghasia, M., Machumu, H., \& de Smet, E. (2019). Micro-credentials in higher education institutions: An exploratory study of its place in Tanzania. The International Journal of Education and Development using Information and Communication Technology. 15(1). pp. 219-230. Retrieved from:

https://www.researchgate.net/publication/329307612 Microcredentials in higher education institutions An exploratory study of its place in Tanzania

Gibson, D., Ostashewski, N., Flintoff, K., Grant, S., \& Knight, E. (2015). Digital badges in education. Education and Information Technologies, 20(2), 403-410. doi: http://dx.doi.org/10.1007/s10639-013-9291-7

Griffith University. (2019). Micro-credentials policy. Retrieved from: https://policies.griffith.edu.au/pdf/Microcredentials.pdf

Griffith University (2018). Digital badges policy. Schedule B: Digital badges taxonomy. Retrieved from: https://policies.griffith.edu.au/pdf/Digital\%20Badges\%20Policy\%20Schedule\%20B.pdf

Griffiths, J. (2018). Review of the Australian Qualifications Framework: Discussion Paper. Queensland Tertiary Admissions Centre Ltd. December. Retrieved from:

https://www.dese.gov.au/system/files/documents/document-file/2020-12/050-queensland-tertiaryadmissions-centre.pdf

Hamson-Utley, J., \& Heyman, E. (2016). Implementing a badging system faculty development. In D. Ifenthaler, N. Bellin-Mularski, \& D-K. Mah, D. (Eds.), Foundation of digital badges and micro-credentials: Demonstrating and recognizing knowledge and competencies (pp.237-258). Switzerland: Springer. https://www.springer.com/gp/book/9783319154244 
Hickey, D., \& Chartrand, G. (2019). Recognizing competencies vs. completion vs. participation: Ideal roles for web-enabled digital badges. Education and Information Technologies, 25, 943-946.

https://doi.org/10.1007/s10639-019-10000-w

Ifenthaler, D., Bellin-Mularski, N., \& Mah, D-K. (Eds.) (2016). Foundation of digital badges and microcredentials: Demonstrating and recognizing knowledge and competencies. Switzerland: Springer. https://www.springer.com/gp/book/9783319154244

IMS Global. (2019). Advancing digital credentials and competency based learning. Retrieved from https://www.imsglobal.org/initiative/advancing-digital-credentials-and-competency-based-learning

Jagger, P. (2019). Digital badging: Is it worth IT? ITNOW. The British Computer Society. December.

Jirgensons, M., \& Kapenieks, J. (2018). Blockchain and the future of digital learning credential assessment and management. Journal of Teacher Education for Sustainability. 20(1), 145-156.

Krupnick, M. (2019). As students flock to credentials other than degrees, quality-control concerns grow. Hechinger Report. Retrieved from: https://hechingerreport.org/as-students-flock-to-credentials-otherthan-degrees-quality-control-concerns-grow/

Leaser, D., \& Gallagher, S. (2017). Convergence of credentials: How corporations and colleges are teaming up to skill up the technology workforce. EDUCAUSE Review. Retrieved from: https://er.educause.edu/blogs/2017/12/convergence-of-credentials

Lewin, A. (2008). Thought leadership in advancing international business research. Basingstoke. England: Palgrave Macmillan.

Liyanagunawardena, T., Scalzavara, S., \& Williams, S. (2017). Open badges: A systematic review of peerreviewed published literature (2011-2015). European Journal of Open Distance and eLearning . 20(2), 116.. Retrieved from: https://www.eurodl.org/materials/contrib/2017/Liyanagunawardena_et_al.pdf

Lumina Foundation. (2019). Counting U.S. Postsecondary and Secondary Credentials. Credential Engine. Retrieved from: https://www.luminafoundation.org/wp-content/uploads/2019/10/countingcredentials.pdf

Mah, D. (2016). Learning analytics and digital badges: Potential impact on student retention in higher education. Technology, Knowledge and Learning, 21(2), 285-305.

Markowitz, T. (2018). The seven deadly sins of digital badging in education. Forbes, September 16, 2018. Retrieved from: https://www.forbes.com/sites/troymarkowitz/2018/09/16/the-seven-deadly-sins-ofdigital-badging-in-education-making-badges-student-centered/\#f412aa770b8b

McArthur, D. (2018). Will blockchains revolutionise education? EDUCAUSE Review. Retrieved from: https://er.educause.edu/articles/2018/5/will-blockchains-revolutionize-education

MicroHE. (2019). The MicroHe approach is based on four pillars. Retrieved from: https://microcredentials.eu/about/

Morris, B. Dragovich, C. Todaro, R., Balci, S., \& Dalton, E. (2019). Comparing badges and learning goals in low and high-stakes learning contexts. Journal of Computing in Higher Education, 31, 573-603. https://doi.org/10.1007/s12528-019-09228-9

My eQuals. (2019). Retrieved from: https://www.myequals.edu.au/

Noonan, P. (2019). Review of the Australian Qualifications Framework. Retrieved from: https://docsedu.govcms.gov.au/system/files/doc/other/aqf review 2019 0.pdf

New Zealand Qualifications Authority (NZQA). (2019). Recognising micro-credentials in New Zealand. Retrieved from: https://www.nzqa.govt.nz/about-us/consultations-and-reviews/recognising-micro-credentials

Newby, T., \& Cheng, Z. (2019). Instructional design badges. Education Technology Research Development, 68, 1053-1067. https://doi.org/10.1007/s11423-019-09719-7

OECD (2019). Getting skills right: Future-ready adult learning systems. Getting Skills Right Series. Retrieved from: https://www.oecd-ilibrary.org/docserver/9789264311756en.pdf?expires=1608005351\&id=id\&accname=ocid56021617\&checksum=88E9E8503924A9DFC0EAABA21 0A8CE67

Oliver, B. (2016). Better 21C Credentials: Evaluating the promise, perils and disruptive potential of digital credentials. Deakin University. Retrieved from: https://www.deakinco.com/media-centre/whitepapers/better-21c-credentials-from-deakin-universitys-professor-beverley-oliver

Oliver, B. (2019a). Making micro-credentials work for learners, employers and providers. Deakin University. Retrieved from: http://dteach.deakin.edu.au/2019/08/02/microcredentials/

Oliver, B. (2019b). Better credentials: Living, learning and earning in 21C. World Conference on Online Learning, Dublin, Ireland. Retrieved from: https://www.assuringgraduatecapabilities.com/goodreads/slides-presented-at-wcol2019

QILT. (2019). Short-term graduate outcomes in Australia. 2019 Graduate Outcomes Survey. October. Retrieved from: https://www.qilt.edu.au/qilt-surveys/graduate-employment 
RMIT Creds. (2019). Retrieved from: https://www.rmit.edu.au/creds

Rossiter, D., \& Tynan, B. (2019). Designing and implementing micro-credentials: A guide for practitioners. Vancouver: Commonwealth of Learning Knowledge Series. Retrieved from: http://oasis.col.org/handle/11599/3279

Roy, S., \& Clark, D. (2019). Digital badges, do they live up to the hype? British Journal of Educational Technology. 50(5), 2619-2636.

Russell, C. (2005). An overview of the integrative research review. Progress in transplantation. 15(1), 8-13.

Sankey, M. (2019). Strategically partnering in co-creating the VLEs of the future. Keynote Address at the Blackboard TLC Asia. Grand Hyatt Hotel, Seoul, South Korea, 14-16 October. Retrieved from: https://www.slideshare.net/michaelsankey/strategically-partnering-in-cocreating-the-vles-of-the-future

Saray, V., \& Ponte, F. (2019). The evolution of a micro-credential. In Y. W. Chew, K. M. Chan, \& A. Alphonso (Eds.), Personalised Learning. Diverse Goals. One Heart (pp. 546-551). ASCILITE 2019 Singapore.

Selvaratnam, R., \& Sankey, M. (2019). Micro-credentialing as a sustainable way forward for universities in Australia: Perceptions of the landscape. ACODE 80 Whitepaper. Retrieved from:

https://www.researchgate.net/publication/337884817 Micro-

credentialing as a sustainable way forward for_universities in Australia_Perceptions of the landsca pe

SkillsFuture (2019). Retrieved from https://www.skillsfuture.gov.sg/

Spaulding, S., \& Johnson, M. (2016). Realizing employment goals for youth through digital badges. Urban Institute. Retrieved from: http://www.urban.org/sites/default/files/publication/80241/2000772-realizingemployment-goals-for-youth-through-digital-badges-lessons-and-opportunities-from-workforcedevelopment.pdf

State University of New York (2019). Micro-credentialing implementation groups. Retrieved from: https://system.suny.edu/academic-affairs/microcredentials/implementation-groups/\#d.en.41529

Tehan, D. (2019) Speech to the AFR Higher Education Summit. 27 August. Ministers for the Department of Education Media Centre. Retrieved from: https://ministers.education.gov.au/tehan/afr-higher-educationsummit

Tehan, D., \& Cash, M. (2020). Marketplace for online microcredentials. Joint Media Release, Ministers' Media Centre, Department of Education, Skills and Employment. 22 June. Retrieved from: https://ministers.dese.gov.au/tehan/marketplace-online-microcredentials

TEQSA (2019) Guidance Note: Technology-Enhanced Learning, Version 1.2, 11 April 2019. Retrieved from: https://www.teqsa.gov.au/latest-news/publications/guidance-note-technology-enhanced-learning

Tierney, G., Horstman, T., \& Tzou, C. (2019). Youth co-design of responsive digital badge systems: Disrupting hierarchy and empowering youth. International Journal of CoCreation in Design and the Arts. Available at: https://doi.org/10.1080/15710882.2019.1654522

Torraco, R. (2005). Writing integrative literature reviews: Guidelines and examples. Human Resource Development Review, 4(3), 356-367.

UNESCO. (2018). Digital Credentialing Report. Retrieved from: https://unesdoc.unesco.org/ark:/48223/pf0000264428

Valideringsdelegationen (2019). A national strategy for validation. Retrieved from: http://www.valideringsdelegation.se/in-english/national-strategy-validation/

Visontay, E. (2020). New $\$ 4.3 \mathrm{~m}$ education website announced by Dan Tehan duplicates existing service. The Guardian. 25 June. Retrieved from: https://www.theguardian.com/australia-news/2020/jun/25/43mshort-course-website-trumpeted-by-dan-tehan-duplicates-existing-service

West, D., \& Lockley, A. (2016). Implementing Digital Badges in Australia: The importance of institutional context. In D. Ifenthaler, N. Bellin-Mularski, \& D-K. Mah, (Eds), Foundation of Digital Badges and MicroCredentials: Demonstrating and recognizing knowledge and competencies (pp.467-482). Switzerland: Springer. Retrieved from: https://www.springer.com/gp/book/9783319154244

World Economic Forum. (2018). The future of jobs report 2018. Retrieved from:

http://www3.weforum.org/docs/WEF Future of Jobs 2018.pd 